\title{
Are the Perceptions of Teachers and Students about Corporal Punishments in Schools Co Related?
}

\author{
Reshmi Ramachandran $^{1 *}$, Dr. G. Subramonian ${ }^{2}$
}

\section{ABSTRACT}

Corporal punishment refers to the use of physical and mental punishment to bring desired changes in the behavior of children. This article explores the relationship between the perceptions of teachers and students towards corporal punishments in schools based on sub scales namely classroom discipline scale, reasons of punishments scale, consequences of punishments scale and alternative to corporal punishments scale. In this article, survey method was adopted with total sample of 180 with 90 each from secondary school teachers and students from Central Kerala. The tool used for measuring the perception of students and teachers were self made tools. On analysis of the data it is understood that perception scores of teachers and students on corporal punishment factors, positive discipline factors, academic factors, psychological factors and alternative factors are unrelated. At the same time when data of the perception scores of teachers and students as per personality factors and sociological factors were analyzed it was found that there is correlation between them.

Keywords: Corporal punishments in schools, classroom discipline scale, reasons of punishments scale, consequences of punishments scale.

Corporal punishments in schools are an old fashioned mode of disciplining still being used in schools all over. Whether be with religious or philosophical backing people inflict punishments on children indiscriminately. Children who are inflicted with them accept it as a natural course of action. Teachers understanding about the gravity of these harmful actions are nil. The teachers seem to be unaware of the harmful effects of these actions whether be in way of psychological or sociological problems, or be physical or mental effects on the child.

\section{REVIEW OF LITERATURE}

Alsaif (2015) explains the lasting effects of corporal punishment on students. The paper first considers the benefits and faults of corporal punishment by comparing the experiences of two generations of students and teachers. The paper concludes with a discussion of the impact of the decision to ban corporal punishment in Saudi Arabian schools on Saudi students and its consequences from the students’ perspective.

\footnotetext{
${ }^{1}$ Research Scholar, Sri Ramakrishna Mission Vidyalaya College of Education (Autonomous), Coimbatore

${ }^{2}$ Associate Professor, Sri Ramakrishna Mission Vidyalaya College of Education (Autonomous), Coimbatore *Corresponding Author

(C) 2015 I R Reshmi, G Subramonian; licensee IJIP. This is an Open Access Research distributed under the terms of the Creative Commons Attribution License (http://creativecommons.org/licenses/by/2.0), which permits unrestricted use, distribution, and reproduction in any Medium, provided the original work is properly cited.
} 
Jaghoory, Bjorkqvist and Osterman (2014) in their study aim at investigating how frequently punishments occur, and their relationship to perpetration of and victimization to peer aggression at school. Data from 649 boys, 595 girls was collected in two cities,both public and private schools in Iran. The results shows that participants who had had their hands burnt (3.8\%), and bones broken (4.8\%) as punishment scored significantly higher on both perpetration of and victimization to almost all types of aggressive behavior at school. Results indicate that EPP by teachers does occur in Iran, in this sample it had been experienced by about 1/20 of respondents, and it was associated with both perpetration of and victimization to aggressive behaviors in school settings.

Save the Children project (2008) made a study with an aim to establish the prevalence of corporal and humiliating punishment on children in both schools and homes. Findings of the study revealed that corporal and other forms of humiliating punishment were known by the pupils (64.5\%). The practice of corporal and humiliating punishment was found to be very high among teachers (90.8\%). Findings show that pupils viewed corporal and humiliating punishment as being good (60\%) whilst teachers felt it was good and it is aimed at developing a child's own self discipline (94.2\%). Corporal and humiliating punishment was mostly administered by class teachers compared to other members of staff in schools. About $11 \%$ of the pupils had even suffered bodily injuries as a result of punishment and this showed the extent of corporal punishment.

\section{NEED OF THE STUDY}

The Right of Children to Free and Compulsory Education (RTE) Act, 2009, which has come into force with effect from 1 April 2010, prohibits 'physical punishment' and 'mental harassment'. It's been five years this Act has been implemented in India. This study is conducted with an intention of understanding the correlation of teachers and students perception about classroom discipline (corporal punishments or positive discipline) is still followed in schools, possible reasons for inflicting punishments (personal or academic reasons), consequences of corporal punishments (psychologically or sociologically) and alternatives of corporal punishments.

\section{STATEMENT OF THE PROBLEM}

Children are the future of any nation. When children are inflicted with punishments they develop a tendency to be aggressive, delinquent or even committing suicides. As there are limited studies undertaken in comparing the perception of students and teachers about corporal punishments in schools researcher here made an attempt to understand 'Are the perceptions of teachers and students about corporal punishments in schools co- related?'

\section{OBJECTIVES OF THE STUDY}

To find out whether there is relationship between perception of teachers and students towards Corporal Punishments based on sub scale namely classroom discipline, reasons of punishments, consequences of punishments and alternatives of corporal punishments. 


\section{HYPOTHESIS OF THE STUDY}

1. There exist no significant relationship between perception scores of teachers and students on classroom discipline as per corporal punishments and positive discipline factors.

2. There exist no significant relationship between perception scores of teachers and students on reasons of punishments as per personality reasons and academic reasons factors.

3. There exist no significant relationship between perception scores of teachers and students on consequences of punishments as per psychological and sociological factors.

4. There exists no significant relationship between perception scores of teachers and students on alternatives of corporal punishments factors.

\section{METHODOLOGY}

\section{a) Method of study}

The present study is descriptive in nature; hence the researcher adopted the survey method for investigation

\section{b) Population and sample}

Population for the present study was identified as secondary schools students and teachers studying in Central Kerala i.e., Palakkad, Ernakulam and Thrissur districts. A sample 90 each from secondary school teachers and students were selected using random sampling method.

\section{c) Tools used for the study}

The tool used for measuring the perception of students were 'Questionnaire for students' [Reshmi Ramachandran and Dr. G Subramonian 2014] and for measuring the perception of teachers ,'Questionnaire for teachers’ [Reshmi Ramachandran and Dr. G Subramonian 2014]. Both consists of four sub scales namely, classroom discipline scale, reasons of punishments scale, consequences of punishments scale and alternatives of corporal punishments scale. Classroom discipline scale consists of two factors namely corporal punishments factors and positive discipline factors. Reasons of punishments scale consists of two factors namely., personality factors and academic factors. Consequences of punishments scale consists of two factors namely. Psychological factors and sociological factors. Alternative to corporal punishments scale consist of only one factor.

d) Variables

Variable of the study are perception towards classroom discipline, reasons of punishments, consequences of punishments and alternatives of corporal punishments on secondary school students and teachers.

e) Statistical techniques used

In this study correlation analysis was done to study the relationship between perception of students and teachers towards corporal punishments in schools 


\section{ANALYSIS, DISCUSSIONS AND FINDINGS}

a) Analysis of data.

Table 1, Data and result of test of relationship between perception of teachers and students towards Corporal Punishments based on sub scale namely classroom discipline, reasons of punishments, consequences of punishments and alternatives of corporal punishments

\begin{tabular}{|c|c|c|c|c|c|c|c|c|}
\hline $\mathrm{H}_{\mathbf{0}}$ & Sub scale & Variables & Category & $\mathbf{N}$ & $\mathbf{M}$ & SD & ' $r$ ' & $\begin{array}{l}\text { Result } \\
\text { at } 0.01 \\
\text { level }\end{array}$ \\
\hline \multirow{4}{*}{1} & \multirow{4}{*}{$\begin{array}{l}\text { Classroom } \\
\text { Discipline }\end{array}$} & \multirow{2}{*}{$\begin{array}{l}\text { Corporal } \\
\text { punishments } \\
\text { factors }\end{array}$} & Teachers & 90 & 11.32 & 4.17 & \multirow[t]{2}{*}{.02} & \multirow[t]{2}{*}{ NS* } \\
\hline & & & Students & 90 & 10.42 & 5.04 & & \\
\hline & & \multirow{2}{*}{$\begin{array}{l}\text { Positive } \\
\text { discipline factors }\end{array}$} & Teachers & 90 & 15.01 & 3.35 & \multirow[t]{2}{*}{-.06} & \multirow[t]{2}{*}{ NS* } \\
\hline & & & Students & 90 & 16.09 & 4.37 & & \\
\hline \multirow{4}{*}{2} & \multirow{4}{*}{$\begin{array}{l}\text { Reasons of } \\
\text { punishments }\end{array}$} & \multirow[t]{2}{*}{ Academic factors } & Teachers & 90 & 19.97 & 7.13 & \multirow[t]{2}{*}{.18} & \multirow{2}{*}{ NS* } \\
\hline & & & Students & 90 & 20.89 & 6.82 & & \\
\hline & & \multirow[t]{2}{*}{$\begin{array}{l}\text { Personality } \\
\text { factors }\end{array}$} & Teachers & 90 & 12.99 & 7.40 & \multirow[t]{2}{*}{.22} & \multirow[t]{2}{*}{$\mathrm{S} * *$} \\
\hline & & & Students & 90 & 20.52 & 7.30 & & \\
\hline \multirow{4}{*}{3} & \multirow{4}{*}{$\begin{array}{l}\text { Consequences of } \\
\text { punishments }\end{array}$} & \multirow{2}{*}{$\begin{array}{l}\text { Psychological } \\
\text { factors }\end{array}$} & Teachers & 90 & 17.42 & 4.27 & \multirow[t]{2}{*}{.11} & \multirow[b]{2}{*}{ NS* } \\
\hline & & & Students & 90 & 21.27 & 3.92 & & \\
\hline & & \multirow[t]{2}{*}{$\begin{array}{l}\text { Sociological } \\
\text { factors }\end{array}$} & Teachers & 90 & 23.32 & 5.20 & \multirow[t]{2}{*}{.33} & \multirow[t]{2}{*}{$\mathrm{S}^{* *}$} \\
\hline & & & Students & 90 & 17.27 & 5.16 & & \\
\hline \multirow[t]{2}{*}{4} & \multirow{2}{*}{$\begin{array}{l}\text { Alternatives of } \\
\text { corporal } \\
\text { punishments }\end{array}$} & \multirow[t]{2}{*}{$\begin{array}{l}\text { Alternative } \\
\text { factors }\end{array}$} & Teachers & 90 & 19.90 & 5.03 & \multirow[t]{2}{*}{-.05} & \multirow[t]{2}{*}{ NS* } \\
\hline & & & Students & 90 & 24.32 & 3.68 & & \\
\hline
\end{tabular}

NS*-Not significant $\mathrm{S}^{* *}$-Significant 


\section{b) Discussion of results}

1 (a)The calculated ' $r$ ' value .02 is lesser than the table value .21 at 0.05 level of significance indicate that there is no significant relationship between perception scores of teachers and students on corporal punishments. Hence hypothesis 1(a) is accepted.

1 (b)The calculated ' $r$ ' value -.06 is lesser than the table value .21 at 0.05 level of significance indicate that there is no significant relationship between perception scores of teachers and students on positive discipline. Hence hypothesis 1(b) is accepted.

2 (a) The calculated ' $r$ ' value .18 is lesser than the table value .21 at 0.05 level of significance indicate that there is significant relationship between perception scores of teachers and students on academic reasons . Hence hypothesis 2(a) is accepted.

2. (b)The calculated ' $r$ ' value .22 is greater than the table value .21 at 0.05 level of significance indicate that there is no significant relationship between perception scores of teachers and students on personality factors. Hence hypothesis 2(b) is rejected. The mean perception score of students as per personality factors (20.52) is higher than that of teachers (12.99).

3 (a) The calculated ' $r$ ' value .11 is lesser than the table value .21 at 0.05 level of significance indicate that there is no significant relationship between perception scores of teachers and students as per psychological factors . Hence hypothesis 3(a) is accepted.

3 (b) The calculated ' $r$ ' value .33 is greater than the table value .21 at 0.05 level of significance indicate that there is no significant relationship between perception scores of teachers and students as per sociological factors. Hence hypothesis 3(b) is rejected. The mean perception scores of teachers as per sociological factors (23.32) is higher than that of students (17.27)

4. The calculated ' $r$ ' value - .05 is lesser than the table value .21 at 0.05 level of significance indicate that there is no significant relationship between perception scores of teachers and students as per alternative factors. Hence hypothesis 4 is accepted.

\section{c) Findings of the study}

On analysis of the data relating to views of teachers and students on corporal punishments and views of teachers and students on positive discipline it was found that there is no correlation between them. So it can be understood that their views about corporal punishments and positive discipline factors are unrelated.

When data relating to the perception scores of teachers and students on academic factors were analyzed, it was found that there is no relationship between their views. At the same time when data of the perception scores of teachers and students as per personality factors were analyzed it was found that there is correlation between them. So it is understood that students consider personality factors as the reason for punishment on students. 
In the meanwhile when the perception scores of teachers and students as per sociological factors were found unrelated. But when psychological factors influence on students was analyzed it is understood that teachers perceive students are psychologically influenced more.

In the end when perception scores of teachers and students as per alternative to corporal punishments factors were analyzed it was found to be unrelated.

\section{CONCLUSION}

Corporal punishments in schools are prohibited in India with effect from the implementation of RTE Act (2009). Understanding the perceptions of students and teachers about corporal punishments will help the policy makers to make appropriate changes. The students need to develop into a citizen who understands the values of respecting others. The world will be a better place if the future citizens of any country live in a healthy environment free from any violence.

\section{REFERENCES}

Alsaif, O.A.(2015). Corporal Punishment In Schools: Theoretical Discussion And Personal Experience. Contemporary Issues in Education Research (CIER). 8(1), 19-24. . Available at: http://www.cluteinstitute.com/ojs/index.php/CIER/article/view/9058.

Committee on the Rights of the Child (2006), General Comment No. 8: The right of the child to protection from corporal punishment and other cruel or degrading forms of punishment (arts. 19; 28, para. 2; and 37, inter alia) (CRC/C/GC/8)

Devi Prasad, B. (2006), Spare the Rod and Save the Child: A Study of the Corporal punishment in urban schools of Andhra Pradesh, Child Rights Advocacy Foundation-Vijayawada.

Essays, UK (2013). Corporal Punishment Across Nations Education Essay. Retrieved from http://www.ukessays.com/essays/education/corporal-punishment-across-nationseducation essay.php?cref $=1$.

Jaghoory,H. K Björkqvist, K. \& Österman, K. (2015). Extreme Physical Punishment by Teachers and its Associations with Aggression and Victimization at School: A Study among Young Adolescents in Iran. Jaghoory, et al., Pediat Therapeut , 5:1.doi:10.4172/2161 0665.1000228

Save the Children. (2008). Prevalence of corporal punishment and other forms of humiliating Punishment on children in Swaziland. Swaziland Report of the Working Group on Eliminating Corporal Punishment in Schools Under Section 17 of the Right of Children to Free and Compulsory Education Act, 2009. New Delhi: National Commission for Protection of Child Rights Right of Children to Free and Compulsory Education Act 2009. Ministry of Human Resource Development. Gazette of India 27 Aug 2009 